\title{
Pathomorphological and Molecular Studies on an Outbreak of Feline Parvo Viral Infection in a Colony of Cats
}

\author{
N. Jayanthi ${ }^{1 *}$, R. Saahithya ${ }^{1}$, N. Pazhanivel ${ }^{1}$, C. Balachandran ${ }^{2}$, \\ G. V. Sudhakar Rao ${ }^{1}$, M. Parthiban ${ }^{3}$ and K. Vijayarani ${ }^{3}$ \\ ${ }^{1}$ Department of Veterinary Pathology, Madras Veterinary College, TANUVAS, Chennai - 7, \\ Tamil Nadu, India \\ ${ }^{2}$ Tamil Nadu Veterinary and Animal Sciences University, Chennai - 51, Tamil Nadu, India \\ ${ }^{3}$ Department of Animal Biotechnology, Madras Veterinary College, TANUVAS, Chennai-7, \\ Tamil Nadu, India \\ *Corresponding author
}

\section{A B S T R A C T}

\begin{tabular}{|l|}
\hline K e y w o r d s \\
$\begin{array}{l}\text { Cats, Feline Parvo Virus, } \\
\text { pathomorphology, } \\
\text { molecular study, } \\
\text { leukopoenia }\end{array}$ \\
\hline Article Info \\
\hline $\begin{array}{l}\text { Accepted: } \\
\text { 15 May } 2018 \\
\text { Available Online: } \\
\text { 10 June } 2018\end{array}$ \\
\hline \hline
\end{tabular}

Sudden death was reported in a colony of cats of which four were brought for necropsy with suspicion for poisoning. All the carcasses showed dehydration and petechial haemorrhages in the conjunctival mucous membrane. Two cats showed epistaxis. Abdominal cavity contained about 20 to $100 \mathrm{~mL}$ of sero-sanguineous fluid. Thickened intestinal wall with grey white mucus mixed contents and miliary grey white foci seen in the mucosa. Meningeal blood vessels were congested. Microscopical examination revealed degenerative changes, sloughed necrotic epithelial cells in the lumen, stunted and blunt villi with dilatation and elongation of the crypts and necrosis of the enterocytes in the intestines. Congestion noticed on the lamina propria and muscular layer. Degenerative and necrotic changes of epithelial cells with focal dilatation were seen in the intestinal crypts. Lymphoid cell depletion and necrosis were observed in the lymph nodes. The above findings were suspicious for feline parvo viral infection which was confirmed by conventional PCR.

\section{Introduction}

Feline Parvo Viral infection (FPV) is a highly contagious viral disease of cats. It is prevalently known by other names viz., feline panleukopenia, feline distemper, feline infectious enteritis, feline ataxia and cat plaque. It is the leading cause of death in cats. Parvo viruses are single stranded non enveloped DNA viruses. Most of the parvo viruses are species specific and tend to infect organs with rapidly dividing cells like bone marrow, intestine and lymphoid tissue (Lamm and Rezabek, 2008).

It is widely prevalent past a century and hence now referred frequently as feline panleukopoenia. 
Feline parvo virus is a small single stranded non enveloped DNA virus which mainly infects domestic cats and other felidae. It is highly contagious and associated with high mortality and morbidity in unvaccinated populations (Hofman-Lehman et al., 1996). About 25 per cent of mortality in kittens in United Kingdom was attributed due to FPV in a retrospective study of 274 cases (Cave $e t$ al., 2002).

However, subclinical infections are prevalent with or without mild symptoms. Infection induces a lifelong immunity and complete elimination of the virus.

The disease is widespread by means of direct contact with the infected cats (faeces, blood, urine) and also transmitted transplacentally. It is highly resistant ad can survive in the environment upto one year (Poole, 1972). After infection, the initial viral replication takes place in the oropharynx followed by widespread systemic dissemination. The viral replication mainly occurs in the mitotically active tissues.

In intestinal tissue it causes profound enteritis and diarrhoea;in lymphoid tissue, it results in profound pancytopenia with cell counts less than 4000 cells/ $\mu \mathrm{L}$ in cats older than 6 weeks of age (August, 1989).

The characteristic symptoms are haemorrhagic gastroenteritis, vomiting, lymphopoenia or leukopoenia. In few cases, the infected cats reveal clinical signs which match to those signs seen when a cat has been poisoned or might have swallowed a foreign object (Parrish, 1995; Steinel et al., 2001; Paltrinieri et al., 2007; Stuetzer and Hartmann, 2014).

The present study describes the outbreak of feline parvo viral infection in a colony of six cats with describes the pathomorphological findings and its molecular detection.

\section{Materials and Methods}

\section{Necropsy examination}

Six cats were presented for necropsy examination to the Department of Veterinary Pathology, Madras Veterinary College, Chennai-600 007 with a history of sudden death. Preliminary history was obtained and necropsy examination was carried out.

\section{Collection of samples}

The tissue samples of $4 \mathrm{~mm}$ thickness of each were collected from intestine, kidney, lymphnodes and liver in 10 per cent formalin in wide mouthed bottles. After fixation, the samples were processed for histopathology. Paraffin embedded tissue sections were cut into $4 \mu \mathrm{m}$ thickness and were stained with haematoxylin and eosin (H\&E). The slides were viewed under light microscopy. The multiple pieces of intestine were collected in freeze packs for polymerase chain reaction and stored in $-20^{\circ} \mathrm{C}$ until further analysis.

\section{Conventional Polymerase Chain Reaction}

PCR was performed on all the intestinal tissue samples collected from the cat colony. DNA isolation kit (QIAamp DNA Mini Kit@, Qiagen, Shriram Enterprises) was used for the DNA extraction from the homogenate obtained from the tissue sample according to the manufacturer's instructions. Genomic DNA was isolated from a healthy cat and was used as negative control along with nuclease free water.

Conventional PCR for the amplification of the VP2 gene was employed by involving the following primer sets and cyclic conditions. The cyclic polymerase chain reaction involved the following steps of denaturation at $94^{\circ} \mathrm{C}$ for one minute, annealing at $55^{\circ} \mathrm{C}$ for one minute, elongation at $72^{\circ} \mathrm{C}$ for two minutes and final 
elongation at $72^{\circ} \mathrm{C}$ for ten minutes. The reaction was set to 35 cycles. The following are the primer sequences used for the study.

The PCR amplicons were electrophoresed in $1 \%$ agarose gel containing $0.5 \mathrm{pg}$ of ethidium bromide per $\mathrm{ml}$ of the gel and visualized in a UV transilluminator (Fotodyne, USA) and photographed using video gel documentation system (Pharmacia, Biotech).

\section{Results and Discussion}

\section{Gross pathology}

The gross morphological changes are represented in the Fig. 1 to Fig. 9. All the carcasses showed dehydration and petechial haemorrhages in the conjunctival mucous membrane of the right eye. Out of the four cats, two cats showed bleeding from the nostrils. Abdominal cavity contained about 20 to $100 \mathrm{~mL}$ of sero-sanguineous fluid in all the cats with congested and edematous lungs. Liver was dark red brown in colour, congestion with diffuse petechiae and pale areas were seen. Spleen was dark black brown in colour with granular parenchyma and diffuse white miliary foci were seen. Kidneys revealed severe congestion and haemorrhages in the cortico-medullary junction. Intestinal wall was thickened with grey white mucus mixed contents and miliary grey white foci observed in the mucosa. Meningeal blood vessels revealed congestion. Blood smear revealed anaemic changes and leukopoenia.

\section{Histopathology}

The histopathology of the respective organs is represented in Fig 10 to Fig. 16. Microscopical examination revealed degenerative changes, sloughed necrotic epithelial cells in the lumen, stunted and blunt villi with dilatation and elongation of the crypts and necrosis of the enterocytes in the intestines. The crypt epithelial cells revealed degeneration and necrosis with focal dilatation. Some of the crypts showed hyperplastic changes. Muscular area and lamina propria of the intestine revealed congestion. Kidneys revealed congestion and haemorrhages, vacuolar degeneration of the tubular epithelium, necrosis and presence of casts and sloughed epithelial cells in a few areas. Lymph nodes revealed lymphoid cell depletion and necrosis.

Congestion, haemorrhage and mild oedema were seen in the lung. Liver revealed sinusoidal congestion. Spleen was congested with lymphoid cell depletion.

\section{Conventional Polymerase chain reaction}

Conventional PCR reaction for the amplification of FPV yielded a product size of 1198bp confirming Feline Parvo Viral Infection (Fig.17).

The present case revealed severe anaemic changes and leukopoenia. The results are in agreement with the findings of Lamm and Rezabek (2008) wherein leukopenia was the salient finding in most of the cases. The occurrence of sudden death in the colony of cats in the current study is similar to the findings of Hammon and Enders (1939) with the major gross findings were reported in the intestine and lymphoid tissue.

They reported that the entire length of small intestine was empty except for a little quantity of bile-stained viscous fluid, while a scanty amount of formed faeces was present in the colon which was characteristic of spontaneous disease occurrence. The other organs revealed congestion and non-specific lesions in the present case which correlated with the earlier findings (Hammon and Enders, 1939; Steinel et al., 2001; Paltrinieri et al., 2007; Stuetzer and Hartmann, 2014). 

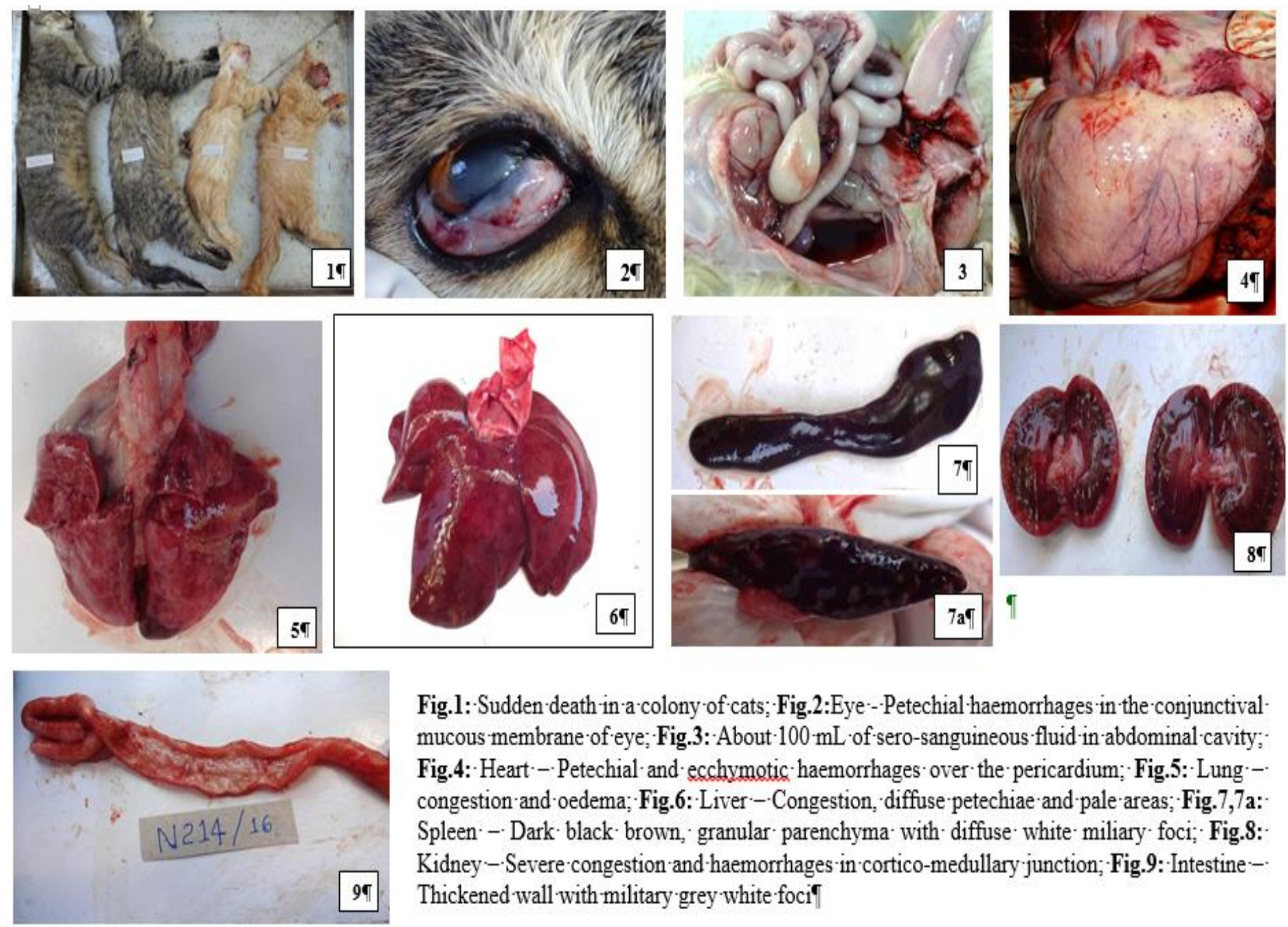

Fig.l: Sudden death in a colony of cats; Fig.2:Eye--Petechial haemorrhages in the conjunctivalmucous membrane of eye; Fig. 3 : About $100 \mathrm{~mL}$ of sero-sanguineous fluid in abdominal cavity; Fig.4: Heart--Petechial and ecchymotic haemorrhages over the pericardium; Fig.5: Lung-congestion and oedema; Fig.6: Liver--Congestion, diffuse petechiae and pale areas; Fig.7,7a: Spleen- - Dark black brown, granular parenchyma with diffuse white miliary foci-' Fig.8:Kidney-Severe congestion and haemorrhages in cortico-medullary junction; Fig.9:-Intestine-Thickened wall with military grey white foci 1 

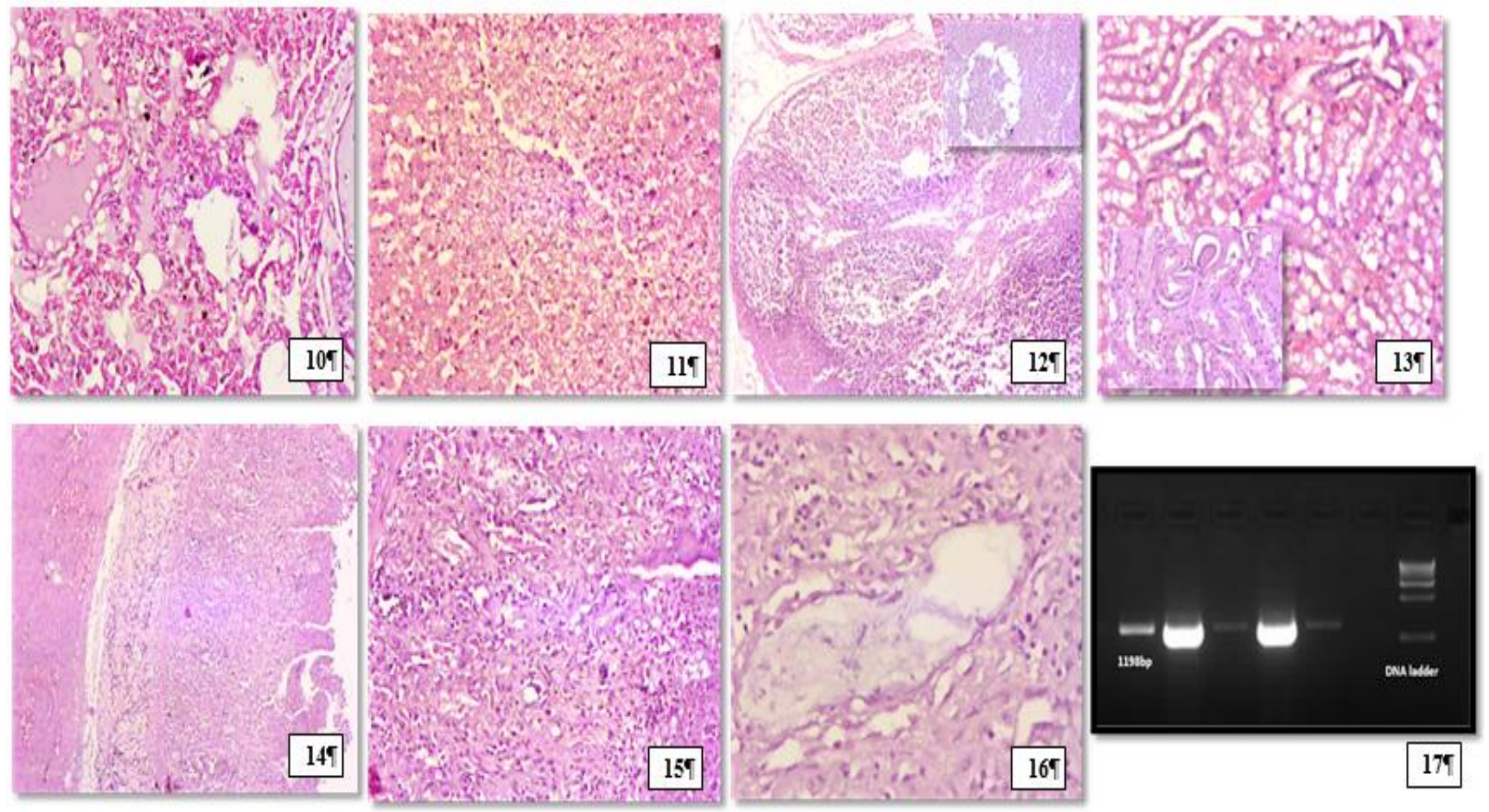

Fig.10:Histopathology - - Lungs - - congestion, haemorrhage and - mild - oedema-(H\&E-20x); Fig.11:-Liver - - sinusoidal-congestion(H\&E-10x);

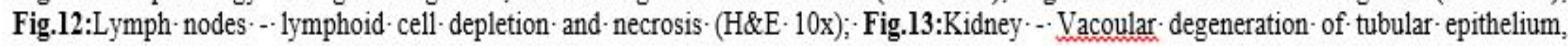

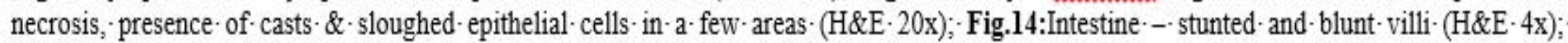
Fig.15:Intestine--Degenerative changes, sloughed necrotic epithelial cells -in the -lumen(H\&E-10x); Fig.16:Intestine--Dilatation-and elongation-

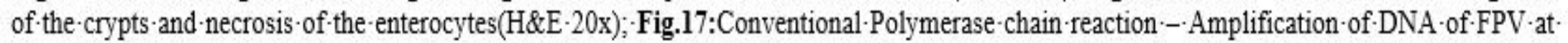
$1198 \cdot \mathrm{bp}_{\mathrm{q}} \mathrm{f}$ 


\section{Conventional Polymerase Chain Reaction}

The histopathological findings are in accordance with the earlier results (Hammon and Enders, 1939; Cave et al., 2002; Lamm and Rezabek, 2008). However, the characteristic intranuclear inclusion bodies were not identified in the above six cases. It may be attributed to the fact stated by Hammon and Enders, 1939 who revealed that the inclusions can be easily demonstrated when the tissues were fixed immediately as soon as the necropsy has been carried out. Delay in the post mortem of the carcass several hours after the death might have resulted in alterations in the mucous membrane in the gland crypts wherein no inclusions could be detected.

The cats were presented to our department several hours after the death of the cats which could be the reason for non-evidence of intranuclear inclusion bodies in the intestinal crypts. In the present case, FPV infection was confirmed by conventional PCR with amplified product at $1198 \mathrm{bp}$ which is in agreement with the earlier reports (Steinel et al., 2000).

FPV infection is now diagnosed not many times by Veterinary professionals, due to the consequence of widespread vaccine use. Even then, infection rates are higher in few unvaccinated cat populations, and the disease occasionally is seen in vaccinated populations despite the frequent use of effective vaccines and pedigreed kittens which were divulged to a high virus challenge.

Hence, the present case was presumptively diagnosed based on leukopenia and characteristic gross and histopathological findings. The confirmatory diagnosis of the case through molecular detection clearly revealed the etiology of FPV infection.

\section{Acknowledgement}

The authors gratefully acknowledge the support from the Department of Animal Biotechnology and especially thank the facilities provided by the Tamil Nadu Veterinary and Animal Sciences University for carrying out the study.

\section{References}

August, J.R., 1989. Feline viral diseases. In: Ettinger SJ, editor. Textbook of Veterinary Medicine, Vol. 1.3rd edition. Philadelphia: WB Saunders; Pp. 314317.

Cave, T.A., Thompson, H., Reid, S.W.J., Hodgson, D.R., and Addie, D.D. 2002.Kitten mortality in the United Kingdom: A retrospective analysis of 274histopathological examinations (1986 to 2000). Veterinary Record. 151: 497-501.

Hammon, W.D., and Enders, J. 1939. Virus diseases of cats. The Journal of Experimental Medicine.69: 327-353.

Hofmann-Lehmann, R., Fehr, D., Grob, M., Elgizoli, M., Packer, C., Martenson, J.S., O'Brien, S.J. and Lutz, H.1996. Prevalence of Antibodies to Feline Parvovirus, Calicivirus, Herpesvirus, Coronavirus, and Immunodeficiency Virus and of Feline Leukemia Virus Antigen and the Interrelationship of These Viral Infections in Free-Ranging Lions in East Africa. Clinical and 
Diagnostic Laboratory Immunology. 3(5): 554-562.

Lamm, C.G., and Rezabek, G.B. 2008. Parvovirus Infection in Domestic Companion Animals. Veterinary Clinics of North America Small Animal Practice. 38: 837-850.

Paltrinieri, S., Crippa, A., Comerio, T., Angioletti, A. and Roccabianca, P. 2007. Evaluation of inflammation and immunity in cats with spontaneous parvovirus infection: consequences of recombinant feline interferon administration. Veterinary Immunology and Immunopathology. 118(1-2): 6874.

Parrish, C.R., 1995. Pathogenesis of feline panleukopenia virus and canine parvovirus. Baillieres Clinical Haematology. 8(1): 57-71.
Poole, G.M., 1972. Stability of a modified, live panleucopenia virus stored in liquid phase. Applied Microbiology. 24: 663664.

Steinel, A., Munson, L., Van Vuuren, $M$ and Truyen, U. 2000. Genetic characterization of feline parvovirus sequences fromvarious carnivores. Journal of General Virology. 81: 345350.

Steinel, A., Parrish, C.R., Bloom, M.E. and Truyen, U. 2001. Parvovirus Infections in Wild Carnivores. Journal of Wildlife Diseases. 37(3): 594-607.

Stuetzer, B., and Hartmann, K. 2014. Feline parvovirus infection and associated diseases. The Veterinary Journal. doi: 10.1016/j.tvj1.2014.05.027.

\section{How to cite this article:}

Jayanthi N., R. Saahithya, N. Pazhanivel, C. Balachandran, G. V. Sudhakar Rao, M. Parthiban and Vijayarani K. 2018. Pathomorphological and Molecular Studies on an Outbreak of Feline Parvo Viral Infection in a Colony of Cats. Int.J.Curr.Microbiol.App.Sci. 7(06): 1800-1806. doi: https://doi.org/10.20546/ijcmas.2018.706.214 